\title{
O CINEMA VAI À GUERRA
}

\section{Liliane Costa Andrade}

Resenha recebida em 28/11/2019 e aprovada em 20/12/2019.

O Cinema vai à Guerra teve sua primeira versão no Laboratório de Estudos do Tempo presente/UFRJ. Fruto de seminários, aulas, palestras, monografias e teses, o livro objetiva rever obras que contam as relações entre cinema e história, utilizando-se de produções cinematográficas como principal fonte, mas não única e, desta forma, colocar a narrativa fílmica como principal concorrente da narrativa histórica.

Observando a sétima arte como uma representação validada devido à sua boa recepção entre o povo e percebendo o aumento na quantidade e qualidade de trabalhos entre cinema e história, a obra a ser resenhada reúne doze estudiosos, sendo três deles os organizadores (Francisco Carlos Teixeira da Silva, Karl Schurster Sousa Leão e Igor Lapsky), para, mesmo com todo o preconceito que há no Brasil sobre uma historiografia baseada no cinema, desenvolver este trabalho que resultou num livro de doze capítulos, publicado em 2015 pela editora ELSEVIER, no qual é discutida a relação entre a guerra e o cinema.

Dando início ao exemplar, Gracilda Alves trabalha com os ideais de Civilizado/Bárbaro e Ocidente/Oriente. Através da análise dos filmes Zulu, Lawrence da Arábica, 55 Dias em Pequim e Gunga Din, a autora mostra a influência destes conceitos nas produções fílmicas. Como consequência destes princípios, surge o fenômeno conhecido como Imperialismo, que é analisado por Karl Schurster e Rafael Pinheiro no segundo capítulo. Nele, os autores apresentam as principais motivações e justificativas que validaram este acontecimento, situado entre os séculos XIX e XX. Além disso, usam as películas 55 Dias em Pequim, Gunga Din e Uma Aventura na África para falar sobre a atuação imperialista na China, na Índia e na África.

No terceiro capítulo, Carlos Leonardo Bahiense da Silva analisa algumas produções cinematográficas que retratam a Primeira Guerra Mundial (1914-1918), um dos acontecimentos históricos mais marcantes da contemporaneidade. Ao todo são trabalhadas oito películas, consideradas pelo autor como sendo as mais fascinantes. Dentre elas estão $O$ Show de Dr. Caligari e Johnny vai à Guerra, onde são evidenciadas as crises nervosas sofridas pelos soldados no conflito; o temor dos combatentes com a mutilação do corpo; e o medo da improdutividade no trabalho.

Dando continuidade, Wagner Pinheiro Pereira expõe como a cinematografia foi afetada na política de Francisco Franco - na Espanha, durante a Guerra Civil Espanhola (1936-1939) - que censurou várias produções e empregou tantas outras como forma de propagandear seu governo ditatorial e fascista. No quinto capítulo, Karl Schurster e Francisco Carlos Teixeira da Silva se dedicam a analisar a Segunda Guerra Mundial (1939-1945), fazendo uma relação entre a guerra e o mal-estar nas diversas narrativas, tendo o cinema como foco central. A normalização do conflito e a dor são algumas temáticas abordadas no texto, e estão presentes nos filmes por eles estudados.

A seguir, os autores Leonardo Bahiense e Ricardo Pinto exploram os filmes Flores do Oriente, O Pianista e Hotel Ruanda a fim de apresentar a diferença entre massacre, genocídio 
e limpeza étnica, defendendo que estes conceitos sejam encaixados na categoria de "eliminacionismo", proposta por Daniel Goldhagen.

Francisco Carlos Teixeira da Silva, escritor do sétimo capítulo, concentra-se em debater a modernização dos conflitos e o surgimento de movimentos pacifistas, que se utilizam das fotografias, da arte e principalmente do cinema para expandir-se e para defender suas ideologias. Dando sequência, Alexandre Busko Valim aborda a relação entre história e cinema durante a Guerra Fria (1947-1991), mostrando a disputa entre Hollywood (Estados Unidos) e Moscou (União Soviética) na produção de filmes que defendiam suas convicções.

A partir da análise dos filmes Apocalypse, Full Metal Jacket e Platoon, Carlos Bahiense e Igor Lapsky tratam, no oitavo capítulo, sobre o trauma dos norte-americanos frente à Guerra do Vietnã (1959-1975), conflito em que foram derrotados por “...uma tropa tecnologicamente inferior, que, mesmo assim, conseguiu ganhar a guerra por meio de táticas de guerrilha e movimentação em matas fechadas (fator fundamental para a vitória dos homens de Ho Chi Minh e Giap)" (BAHIENSE; LAPSKY, 2015, p. 205).

Dilton Cândido Maynard e Andreza S. Cruz Maynard examinam, no capítulo intitulado de A Guerra Entre Mundos: Não Estamos Sozinhos!, as produções de ficçãocientífica hollywoodianas que colocam o telespectador frente a alienígenas, grupo formado por latinos, índios, negros, comunistas, rebeldes, mulçumanos e pobres, que representam riscos ao Americam Way Of Life.

Penúltimo capítulo do livro, A Guerra ao Terror: O Pós-Guerra Fria, escrito por Igor Lapsky, relata o ataque terrorista de 11 de setembro de 2001 ao World Trad Center, nos Estados Unidos, promovido pela Al-Qaeda, e apresenta algumas produções de Hollywood que retratam o terrorismo sofrido pelos norte-americanos, desde os seus primórdios até se classificar como uma das consequências da Guerra Fria. Por fim, o autor José Maria Gomes de Souza Neto mostra como a distopia se faz presente nos filmes A Revolução dos Bichos, Minority Report, Akira e $O$ Deserto de Tártaros.

Considerando a proposta do livro e analisando a maneira como o mesmo foi desenvolvido, considero que este atingiu seus objetivos de maneira adequada. Baseando-se em diversas fontes, de livros a trabalhos científicos, e analisando variados filmes, os autores conseguem abordar diferentes guerras em momentos e realidades distintas, de maneira a dedicar-se às duas principais temáticas da obra. Porém, a grande quantidade de películas trabalhadas, principalmente no terceiro capítulo, e o custo para ter acesso a algumas delas, podem dificultar a escolha dos leitores que pretendam empregá-las.

Mesmo assim, O Cinema Vai à Guerra é uma opção pertinente de livro para professores que queiram aplicar filmes em sala de aula, para pesquisadores de cinema e de guerra, e principalmente para quem tem interesse em iniciar estudos nessa área visto que, possui uma linguagem de fácil compreensão, expõe a análise das produções cinematográficas de maneira bastante didática e completa, além de ser objetivo quanto ao que foi proposto.

\section{Nota}

${ }^{\text {I }}$ Mestranda em História Comparada pela Universidade Federal do Rio de Janeiro (PPGHC/UFRJ). Bolsista CAPES. Integrante do Grupo de Estudos do Tempo Presente (GET/UFS/CNPq). E-mail: Cadernos do Tempo Presente, São Cristóvão-SE, v. 11, n. 01, p. 104-106, jan./jun. 2020 http://www.seer.ufs.br/index.php/tempo 
O CINEMA VAI À GUERRA

LILIANE COSTA ANDRADE

liliane.costaandrade@outlook.com. Orientador: Prof. Dr. Dilton Cândido Santos Maynard (ProfHistória/UFS - PPGHC/UFRJ).

\section{Referência Bibliográfica:}

SILVA, Francisco Carlos Teixeira da; LAPSKY, Igor; LEÃO, Karl Schurster Sousa. O Cinema vai à Guerra. Rio de Janeiro. Elsevier - Campus, 2015. 